\title{
Article 24C Paragraph 1 of the 1945 Constitution of the Republic of Indonesia: History and Critical Analysis of Disputes on the Authority of State Institutions
}

\author{
Demas Brian Wicaksono \\ Universitas 17 Agustus 1945 Banyuwangi, Indonesia \\ Email: demasbrian03@gmail.com
}

\begin{abstract}
:
In simple terms, the ratio legis can be interpreted as the reason why there is a provision in the law. Article 24C paragraph (1) of the 1945 Constitution of the Republic of Indonesia determines the authority possessed by the Constitutional Court, paragraph (1) reads: The Constitutional Court has the authority to adjudicate at the first and final levels whose decisions are final to examine laws against the Constitution, decide disputes over authority a state institution whose authority is granted by the Constitution, decides on the dissolution of political parties, and decides on disputes regarding the results of general elections. The limiting provisions of Article 24C paragraph (1) seem to close the scope for expanding the Constitutional Court authority to decide disputes over the authority of independent state institutions. Meanwhile, this is a state requirement. This research uses a statutory approach with a descriptive analysis method. The conclusions obtained are: 1) it is not possible that a state institution that has supervisory authority has conflict with other legal institutions; 2) there are state institutions whose authorities are regulated by law and have the potential for authority disputes, but are resolved through the executive agency; 3) there is the authority of state institutions that have the potential for conflict of authority but there are no rules for resolving them.
\end{abstract}

\section{Keywords:}

ratio legis; contitutional court; article 24 C section (1)

\section{Introduction}

The formulation of legal norms in legislation has a reason or purpose, because it contains the politics of state law. To find out the reason or purpose of formulating legal norms in a law, it is necessary to look for and find the legal ratio. Black's Law Dictionary defines the ratio legis as "the reason or occasion of law; the occasion of making a law; the reason of law is the soul of law". Verena Klappstein stated in practical discourse, the use of the ratio legis means:

a. real intention of a lawgiver or judge (reason provided or implied);

b. consider that caused a lawgiver to enact certain legislative acts or a judge to impose a certain sentence;

c. subjective aim of a statute (or the sentence)

d. (re)constructed intention of a lawgiver or judge (reason lawgiver or judge should have).

e. type of constructed legal argument ascribing an intention or a reason to a lawgiver (or judge);

f. objective aim of a statute (or sentence);

g. particular aim of a statute or sentence (relevant in certain circumstances);

h. all aims of a statute or sentence;

i. justification (external, justificatory reason) for certain legislative or judicial acts); 
In this section, the discussion is focused on the search for the ratio legis $24 \mathrm{C}$ Paragraph (1) of the 1945 Constitution of the Republic of Indonesia. In principle, this discussion is one of the main problems that will be discussed in this dissertation. The study regarding the search for the ratio legis of a provision has a very important urgency to be written in a dissertation as mentioned by Peter Mahmud Marzuki, that if in an academic work to be explored is the philosophy and ratio legis of a provision then it has entered the realm of dissertation writing.

Furthermore, talking about the ratio legis of a statutory provision in principle is closely related to the study of legal politics, it can also be said that exploring the reasons or backgrounds of legislators in formulating a provision is identical to finding out what legal politics is behind a provision. This is based on the opinion of Mahmud MD which states that the study of legal politics includes at least three things: First, the official line of state policy regarding the law that will be enacted or not enforced to achieve state goals; Second, the political, economic, social, cultural background (poleksosbud) that influences the birth of legal products; Third, law enforcement in the field reality.

\section{Research Methods}

In legal research activities there are several elements used by the author, namely the problem approach is the process of solving or solving problems through predetermined stages so as to achieve research objectives. To discuss the problems contained in this research proposal, the author uses a statute approach approach. The type of legal research used is normative legal research, focusing on legal issues regarding legal certainty in resolving investor disputes with the legal community in the perspective of legal pluralism.

In this case, the laws and regulations relating to the settlement of investor disputes with indigenous peoples in the land sector. On the other hand, secondary legal materials are also used, in the form of all publications on law which are official documents, publications on law, including books, legal journals, and comments on court decisions, as well as tertiary legal materials, namely materials that provide guidance. As well as explanations of primary legal materials and secondary legal materials, such as legal dictionaries and internet articles. Analysis of the data used in writing this legal research is a descriptive analysis method.

\section{Discussion}

\subsection{History of Analysis 24c Paragraph (1) of the 1945 Constitution of the Republic of Indonesia Concerning Authority Disputes}

In the BPUPKI session, Mohammad Yamin initiated an institution authorized to resolve disputes in the field of implementing the constitution. The institution is constitutionnelle geschil or constitutional disputes. Yamin's idea started with the idea of the need to apply a materieel toetsing recht (material test) to the law. The proposed institution to have this authority is the Supreme Court. However, Soepomo refuted this with four reasons that (i) the basic concept adopted in the Constitution which is being drafted is not the concept of separation of power but the concept of distribution of power, in addition, (ii) the task of judges is to apply laws and regulations. the law, not testing the law, (iii) the authority of judges to conduct judicial review is contrary to the concept of supremacy of the People's Consultative Assembly, and (iv) as a newly independent country, it does not yet have experts on this matter and experience regarding judicial review. 
The idea of forming a Constitutional Court in the reform era began to be put forward during the second session of the Ad Hoc Committee I of the MPR RI Working Body (PAH I BP MPR), namely after all members of the MPR RI Working Body conducted a comparative study in 21 (twenty-one) countries regarding the constitution in March-April 2000. This idea did not appear at the time of the first amendment to the 1945 Constitution, not even a single faction in the People's Consultative Assembly (MPR) had put forward the proposal. It seems that the MPR members were greatly influenced by their findings in the comparative study. However, at the annual session of the People's Consultative Assembly in August 2000, the draft formulation regarding the Constitutional Court was still a non-final alternative.

The history of the establishment of the Constitutional Court (MK) began with the adoption of the idea of a Constitutional Court (Constitutional Court) in the constitutional amendments carried out by the People's Consultative Assembly (MPR) in 2001 as formulated in the provisions of Article 24 paragraph (2), Article 24C, and Article 7B. The 1945 Constitution was the result of the Third Amendment which was ratified on November 9, 2001. The idea of establishing the Constitutional Court was one of the developments of modern legal and state thought that emerged in the 20th century.

After the ratification of the Third Amendment to the 1945 Constitution, in order to wait for the establishment of the Constitutional Court, the MPR determined that the Supreme Court (MA) would temporarily carry out the functions of the Constitutional Court as stipulated in Article III of the Transitional Rules of the 1945 Constitution resulting from the Fourth Amendment. The DPR and the Government then drafted a Law on the Constitutional Court. After going through in-depth discussions, the DPR and the Government jointly approved Law Number 24 of 2003 concerning the Constitutional Court on August 13, 2003 and was ratified by the President on that day (State Gazette Number 98 and Supplement to the State Gazette Number 4316).

Two days later, on August 15, 2003, the President through Presidential Decree No. $147 / \mathrm{M}$ of 2003 inaugurated constitutional judges for the first time, followed by the oath of office of the constitutional judges at the State Palace on August 16, 2003. Case from the Supreme Court to the Constitutional Court, on October 2003 which marked the start of the operation of the Court's activities as a branch of judicial power according to the provisions of the 1945 Constitution. The 1945 Constitution of the Republic of Indonesia affirms that sovereignty rests with the people and is implemented according to the Constitution. In addition, it was also emphasized that the Indonesian state is a state of law, which requires that all actions or actions of the authorities have a clear legal basis or have legality, both based on written law and unwritten law.

In line with the above constitutional principles, one of the important substances in the amendment to the 1945 Constitution of the Republic of Indonesia is the existence of the Constitutional Court as a state institution that functions to handle certain cases in the administrative field, in order to maintain the constitution so that it is carried out responsibly in accordance with the will of the people and democratic ideals. The existence of the Constitutional Court is at the same time to maintain the implementation of a stable state government, and is also a correction to the past experience of state administration caused by the double interpretation of the constitution.

The existence of the Constitutional Court is regulated in Article 24C paragraph (1) and paragraph (2) of the 1945 Constitution of the Republic of Indonesia. Amendments which were later reaffirmed in Law no. 24 of 2003 concerning the Constitutional Court. Since 2003, 
the Constitutional Court has opened itself to accept requests from people who feel that their constitutional rights and authorities have been violated due to the enactment of a law. At first this function was not used properly by the community, but along with the development of time and the growth of public awareness, from 2004 to 2010 quite a number of cases were submitted and examined by the Constitutional Court. In fact, some of the cases that have been submitted have already had a legal determination with the decision being made by the Constitutional Court. Saragih (2020) stated that in law and mass media studies, morals and ethics are linked to the obligations of journalists, such as; implementation of journalistic code of ethics in every journalistic activity, subject to legal institutions and regulations to carry out with good etiquette as the provisions in the law which are a set of principles and rules that have generally been accepted and approved by the community.

The establishment of the Constitutional Court marks a new era in the judicial power system in Indonesia. Some areas that were previously untouchable by law, such as judicial review of laws, can now be carried out by the Constitutional Court, including other powers regulated in the 1945 Constitution after the amendment. In the context of recognizing and understanding the urgency of the establishment of the Constitutional Court as one of the actors of judicial power in Indonesia more fully, this paper will discuss several issues that are closely related to it, including at a glance the formation of the Constitutional Court in Indonesia, the organizational structure of the Constitutional Court, procedural law. The Constitutional Court, the legal principles and sources of law that are used as references for the Constitutional Court in carrying out its judicial duties and authorities. The emergence of the Constitutional Court as an actor of judicial power is expected to be an entry point that encourages the realization of a modern judicial power system in Indonesia.

The Constitutional Court was established with the function of ensuring that no more legal products will come out of the corridors of the constitution so that the constitutional rights of citizens are protected and the constitution itself is protected for its constitutionality. In practice, several decisions of the Constitutional Court have caused doubts because there are inconsistencies in the decisions taken. Such as decision No. 16/PUU-VIII/2010 which states that a judicial review can only be carried out once, but Decision No. 34/PUU-XI/2013 states that a judicial review can be carried out more than once.

The limiting provisions of Article 24C paragraph (1) seem to close the scope for expanding the MK's authority to decide disputes over the authority of independent state institutions. Meanwhile, this is a state requirement. In this regard, it is interesting to observe the provisions of Article 29 paragraph (1) of Law No. 48 of 2009 concerning Judicial Power. Paragraph (1) reads: The Constitutional Court has the authority to adjudicate at the first and final levels whose decisions are final for: a. Examine the law against the 1945 Constitution of the Republic of Indonesia; b. To decide on disputes over the authority of state institutions whose authorities are granted by the 1945 Constitution of the Republic of Indonesia; c. Decide on the dissolution of a political party; d. Decide on disputes about the results of the general election; and e. Other powers granted by law.

It seems that the provisions in letter e of Article 29 paragraph (1) of Law No. 48 of 2009 concerning Judicial Power above is intended as a justification or legal basis for the granting of "additional" authority given to the Constitutional Court to hear and decide on disputes over the results of regional head elections. This is evident from the Elucidation of Article 29 paragraph (1) letter e of the Law on Judicial Power which reads, "This provision includes the authority to examine and decide disputes over the results of regional head elections in accordance with the provisions of the legislation." In this regard, I Dewa Gede 
Palguna is of the view that, theoretically, there are two problems that arise from the above provisions. First, substantially, it is clear that Article 29 paragraph (1) letter e of the Law on Judicial Power above has added new authority to the Constitutional Court.

It is said to be a "new authority" because that authority is not at all a derivative or derivation of the authority that has been explicitly stated in the 1945 Constitution of the Republic of Indonesia, in this case Article 24C paragraphs (1) and (2). The question that then arises is whether the law can add new powers that are not at all mentioned in the formulation of Article 24C paragraphs (1) and (2) of the 1945 Constitution which limitatively regulates the authority of the Constitutional Court. Regarding this, I Dewa Gede Palguna is of the view that "no." Because, in this way means there has been a change to the Constitution NRI Year 1945 which was not done by an authorized state agency (MPR) and according to the procedures set forth in Article 37 based on NRI Constitution of 1945.

Second, even supposing the addition of the authority as done Article 29 paragraph (1) letter e of the Law on Judicial Power above can be justified, quad non, it can still be questioned because the "addition" of authority to the Constitutional Court, namely to decide disputes over the results of the vote count for regional head elections, has been carried out since 2008, namely through Article 236C of Law No. 12 of 2008 concerning the Second Amendment to Law No. 32 of 2004 concerning Regional Government, while the Law on Judicial Power was promulgated on October 29, 2009. Article 236C of Law No. 12 of 2008 states: "The handling of disputes over the results of the election of regional heads and deputy regional heads by the Supreme Court is transferred to the Constitutional Court no later than 18 (eighteen) months from the promulgation of this Law." Thus, once again, even if the method of adding authority as carried out by Article 29 paragraph (1) letter e of the Judicial Power Act above can be justified, then this provision only serves to explain the granting of "additional" authority to the Constitutional Court and not as a legal basis granting authority.

This is very different from the case if the phrase "other powers granted by law" in letter e of Article 29 paragraph (1) of the Law on Judicial Power appears or becomes part of Article 24C paragraph (1) of the 1945 Constitution of the Republic of Indonesia.134 Thus, if a law, including the judicial law, grants other authorities other than those explicitly stated in Article 24C paragraph (1) of the 1945 Constitution of the Republic of Indonesia, that authority is a derivation or derivation from the 1945 Constitution of the Republic of Indonesia, not adding authority. In other words, the law only makes more explicit an authority that has been implicitly stated in the 1945 Constitution of the Republic of Indonesia. So, in the latter case, substantially the law does not take up the content material which is the content of the constitution and is the procedural law also does not violate the procedure for amending the constitution as stipulated in Article 37 of the 1945 Constitution of the Republic of Indonesia and its authority rests with the legislators, namely the MPR, not in the hands of the legislators.135 Based on Article 24 paragraph (2) of the Constitution 1945 as a result of the third amendment, the Constitutional Court is one of the institutions that exercise judicial power. Then in Article 24C paragraph (1) of the 1945 Constitution of the Republic of Indonesia it is emphasized that "The Constitutional Court has the authority to adjudicate at the first and final level whose decisions are final to examine laws against the Constitution, to decide on disputes over the authority of state institutions whose authority is granted by the Constitution. The Constitution, decides on the dissolution of political parties, and decides on disputes regarding the results of the general election". 
This is the constitutional basis for the authority of the Constitutional Court to examine, adjudicate, and decide on disputes over authority among state institutions whose authority is granted by the 1945 Constitution of the Republic of Indonesia. Based on Article 2 of Law Number 24 of 2003 concerning the Constitutional Court, it is stated that the Constitutional Court is one of the state institutions exercising the power of an independent judiciary to administer justice to uphold law and justice. Judging from this provision, the authority of the Constitutional Court to decide disputes over authority between state institutions is a manifestation of the exercise of judicial power possessed by the Constitutional Court. One of the powers of the Constitutional Court as stated in the provisions of Article 24C paragraph (1) of the 1945 Constitution of the Republic of Indonesia is to settle disputes over authority between state institutions whose authority is granted by the Constitution. With regard to disputes that can be submitted to the Constitutional Court, the 1945 Constitution has clearly regulated and set limits, namely; 1 . Regarding authority disputes. The main dispute that can be submitted to the Constitutional Court is a dispute over authority, not other disputes. As for the sources of authority in dispute, both those originating from the 1945 Constitution of the Republic of Indonesia and from other laws and regulations; 2. The disputed state institutions and state institutions in question are only state institutions whose authority is granted by the 1945 Constitution of the Republic of Indonesia. Thus, state institutions that obtain authority other than the 1945 Constitution of the Republic of Indonesia cannot file a petition for disputes on authority between institutions at the Constitutional Court.

Furthermore, disputes over the authority of state institutions whose authority is granted by the 1945 Constitution of the Republic of Indonesia are regulated in Law Number 24 of 2003 concerning the Constitutional Court. The law stipulates that those who can submit applications to the Constitutional Court in disputes over the authority of state institutions are state institutions whose authority is granted by the 1945 Constitution of the Republic of Indonesia and these institutions have a direct interest in the disputed authority. From these provisions, there are three criteria for filing a dispute over a state institution in the Constitutional Court: namely, a. Regarding authority disputes, and not other disputes; b. The parties are state institutions whose authority is given by the 1945 Constitution of the Republic of Indonesia; c. The said state institution has a direct interest in the disputed authority.

Today in the constitutional system in force in Indonesia, the legal aspects of implementing the decisions of the Constitutional Court-RI are listed in Article 24C paragraph (1) of the 1945 Constitution (results of amendments). The provision is relatively firm, saying that the Constitutional Court has the authority to adjudicate at the first and final levels whose decisions are final..." Then, the dictum of Article 10 paragraph (1) of Law 24/2003 concerning the Constitutional Court reaffirms that the Constitutional Court has the authority to adjudicate at the first and final levels whose decisions are final for examine the Act against the 1945 Constitution, decide on disputes over authority between state institutions whose authority is granted by the 1945 Constitution, decide on the dissolution of political parties and decide disputes over election results. If these provisions are read carefully, none of the two different levels of legal instruments contains the word binding. This is a fatal error produced by the MPR in the Second Amendment to the 1945 Constitution. In fact, the articulation of the final decision is incomparable. The consequences cannot be compared, the final decision must be normatively binding. Therefore, everywhere the final word is always accompanied by the word binding or final and binding. Moreover, although the words final and binding have been explicitly stated in the constitution and laws governing the authority of the Constitutional Court, the final decision of the guardian of constitutional order is often ignored by the organs of law. Especially if you don't include it. 
Thus, although it has been stated clearly that the Constitutional Court's decision is final and binding, empirical facts show that not all final and binding decisions can affect the parliament and other state institutions (non-judicial actors). That is why, the existence of a regulation that regulates the authority and legal consequences of the final decision of the Constitutional Court, does not necessarily have real implications for the application of its decision. What in Indonesia may be perceived as non-binding. This problem is caused by two things. First, the Constitutional Court does not have an execution unit tasked with guaranteeing the application of the final decision (special enforcement agencies). Second, the final decision is highly dependent on the willingness of public authorities outside the Constitutional Court to follow up on the final decision. Such a framework of thinking gave birth to the stance that the task of the constitutional court is not only to carry out interpretation activities, but also to bear a great responsibility so that the constitutional provisions are implemented.

State life that is aware of the importance of the constitution actually lays down appropriate procedures to be used to resolve legal disputes. For example, in the United States, almost all products of the Supreme Court's final examination go through a testing process which the legal community calls IRAC. This stands for: (1) [i]identify the issue; (2) state the [r] rule of law; (3) [a] analyze the fact and the law; and (4) reach some [c]conclusion. 18 Thus the final and binding decision of the Supreme Court is assumed to be the product of a balance test between various factors that significantly affect the results of the test on all controversial elements. Final and binding decisions of the Supreme Court must demonstrate a coherent degree of precision and accuracy. And this decision is often considered as a work of analysis carried out in stages, et cetera, positioning the constitution as the first and last reference. The problems that exist in the application stage of the final decision must make us more aware that the final decision is in dire need of revitalization. This is the accumulated energy of the majority rule. As a result of this energy accumulation, the judges (the constitution) are expected to be able to maintain an equilibrium of political support. This means that the application of the final decision requires intensive pressure from other state institutions. Therefore, the expectation of an implementable final decision is not only influenced by legal considerations and the personal policy choices of the judges (the constitution). However, they must also pay attention to strategic factors such as; public perception of the problems faced, the interests of the majority layer and the rights of minorities that should not be ignored.

Constitutional Justices are state officials. As state officials, the protocol position and financial rights of the Chair, Deputy Chair, and members of the constitutional judges apply the provisions of laws and regulations for state officials. Constitutional judges may only be subject to police action on the orders of the Attorney General after obtaining written approval from the President, except in the case of: a. caught in the act of committing a crime; or b. based on preliminary evidence that is reasonably suspected to have committed a crime punishable by the death penalty or a crime against state security. For the smooth implementation of its duties and authorities, the Constitutional Court is assisted by a Secretariat General and Registrar. Provisions regarding the organizational structure, functions, duties and authorities of the Secretariat General and Registrar of the Constitutional Court shall be further regulated by a Presidential Decree on the recommendation of the Constitutional Court. While the budget of the Constitutional Court is charged to a separate budget item in the State Budget (APBN). This includes all costs required for the implementation of the duties of the Secretariat General and the Registrar of the Constitutional Court shall be borne by the State Revenue and Expenditure Budget. On June 22, 2004, President Megawati Soekarnoputri issued Presidential Decree No. 51 of 2004 concerning the Secretariat General and the Registrar of the Constitutional Court. This Presidential Decree was issued in the context of 
providing support in the technical administrative and administrative justification fields. The Constitutional Court, it is deemed necessary to determine the Organization of the Secretariat General and the Registrar of the Constitutional Court.

The DPR together with the President have given approval to stipulate the revision of the Constitutional Court Bill (RUU MK) as Law (1 September 2020). There are various notes that can be a reflection of the logic of thinking from the formulation of the law (ratio legis). Among the main points in the revision of the bill are the age requirement to become a judge of the Constitutional Court, the tenure of the judges of the Constitutional Court, the addition of the personnel of the Ethics Council of the Constitutional Court, and the addition of the principle of transparency in the selection of judges which is still being submitted from 3 (three) state institutions (DPR, President and MA) and does not add revisions related to disputes over the authority of state institutions.

\subsection{Comprehensive Text Analysis of the 1945 Constitution of the Republic of Indonesia concerning Disputes on the Authority of State Institutions}

Legal certainty is the ultimate goal of law. Dogmatic jurisprudence that adheres to a positive legal system requires certainty so that a rule can be enforced after the legal norm is declared valid. The formulation of legal norms in legislation cannot be separated from the purpose of the establishment of a legislation, so in the purpose of the formulation we also need to know about the legal politics of the existence of these rules. Similarly, in the 1945 Constitution of the Republic of Indonesia when we want to know more about what is the background for the formulation of the articles in it, we first study the comprehensive text of the 1945 Constitution of the Republic of Indonesia so that we can find out what things are behind each article and what only the discussion so that it is arranged into the articles listed as currently enforced.

Next One of the debates that has arisen is the limitation of disputes that can be submitted to the Constitutional Court. Whether all disputes involving state institutions can be submitted to the Constitutional Court or not. Regarding this matter, Asnawi Latief from FPDU again said that according to him, disputes that can be submitted to the Constitutional Court are disputes between state institutions in the context of implementing laws and regulations.

Then the problem with our faction is that if the Supreme Court is given the right to judicial review, as it is now, so that it is maintained, then the Constitutional Court is not needed. However, if the Supreme Court is really only focused on matters relating to the Ansich Court, then a Constitutional Court is needed. So that the tasks that we have been trying to propose in the formulation of Article 24A concerning the right to judicial review of the laws and regulations, we delegate to the Constitutional Court.

In addition, he has the authority to make decisions on conflicts or disputes between institutions in carrying out statutory regulations. Because the second one is the other day, it is necessary to have a Constitutional Court if there is a conflict in implementing the laws and regulations who has the right to give a decision. We do not agree to give it to the Supreme Court. So that a new idea was born to create a Constitutional Court and it is also the result of comparative studies in many countries that such a court is needed. Therefore, if these powers are agreed upon, our faction agrees that the Constitutional Court will also issue additional proposals for the resolution of election disputes, after all, wong there will be no later in the next article, I will generally review that it concerns the dispute, which is the authority of the Constitutional Court. 
As the opinion above states the description of the proposal related to conflicts or disputes between state institutions in carrying out laws and regulations, which means that the settlement that is expected to be regulated is related if there is a conflict/dispute between state institutions in which the conflict/dispute is the result of carrying out the statutory arrangements and opinions above. does not agree if the authority to decide disputes over authority between state institutions is given to the supreme court and more agrees if the authority is given to the constitutional court, but it is not explained in more detail what the reason for the faction does not agree that the authority to settle disputes over authority between state institutions is given to the supreme court.

This opinion then becomes an interesting matter regarding the statement "authority over decisions on conflicts or disputes between institutions in carrying out statutory regulations" is a sentence that is understood to be a dispute over the authority of state institutions arising from carrying out legal arrangements within the scope of legislation, which means that all State institutions that exercise authority in the name of legislation may experience authority disputes between State institutions and may become parties to the dispute. If the authority referred to in question is understood to mean all state institutions in carrying out their authority based on statutory regulations, whether state institutions in carrying out the authority of a law are part or always derivatives of a constitution which seems unclear and the direction of the discussion cannot be understood.

So according to the author, regarding the purpose of the statement of the faction stating "the authority over decisions on conflicts or disputes between institutions in carrying out statutory regulations" must be clearer again regarding the authority over the laws and regulations, if it turns out that the authority of the State institution that is carried out is in the context of exercising its authority. Constitutionally, this authority can become the authority of the constitutional court. But later it will be a problem again if the authority turns out to be not part of the constitutional authority, then it is possible that the dispute over authority between these state institutions cannot be resolved because the proposed settlement efforts are not submitted to the Supreme Court but through the Constitutional Court. If it then understood that the proposed arrangement is indeed intended for all State institutions that carry out laws and regulations that are understood in such a simple way, then this will later become the rationale for the formation of further arrangements in the regulation of dispute resolution between State institutions.

\section{Conclusion}

First, there are institutions that do not have the potential to experience conflict of authority with other institutions because they have special powers, for example the "handling" authority by the KPK which is Privilege to the legal process of corruption which allows other institutions to not take the authority of the KPK in carrying out the legal process on a corruption case.

Second, there are state institutions whose powers are regulated by law and have the potential for authority disputes, but are resolved through the executive agency related to Military Operations Other Than War (OMSP) of the Indonesian National Army (TNI) and the Indonesian National Police (POLRI). This may allow for a conflict of authority between the Indonesian National Police in carrying out the authority to maintain public/civil order based on Article 14 letter i of Law Number 2 of 2002 concerning the Indonesian National Police and at the same time the TNI also exercises its authority in OMSP. 
Third, there is the authority of state institutions that have the potential for conflict of authority but there are no rules for resolving them, for example, the authority of the National Human Rights Commission in determining an event constitutes a criminal act of a serious human rights crime as regulated in Law No. 26 of 2000 concerning the Human Rights Court.

\section{References}

Abdulkadir Muhammad. 2004, Hukum dan Penelitian Hukum, Citra Aditya Bakti. Bandung. p.112

Aditya Wiguna Sanjaya, Rekonstruksi Bentuk Kesalahan Dalam Tindak Pidana Pencucian Uang Pasif, 2020.

Ahmad Fadlil Sumadi, "Hukum Acara Mahkamah Konstitusi dalam Teori dan Praktik", Jurnal Konstitusi, Volume 8, Nomor 6, Desember 2011, p. 849.

A. Muktie Fajar, 2006, Hukum Konstitusi Dan Mahkamah Konstitusi, Jakarta: Sekretariat Dan Kepaniteraan Mk Ri, p. 119.

Asr Agustiwi, 'Keberadaan Lembaga Negara Pasca Amandemen Undang-Undang Dasar 1945 di Indonesia', RECHSTAAT Ilmu Hukum Fakultas Hukum UNSA, vol. 8, no. 1 (2014), pp. 1-10.

Bekti Suharto, 'Menyoal Sudut Pandang: Kritik Terhadap Epistemologi Positivisme Hukum', Prosiding Seminar Nasional (2015).

Dachran Busthami, 'Kekuasaan Kehakiman Dalam Perspektif Negara Hukum Di Indonesia', Masalah-Masalah Hukum, 2018 <Https://Doi.Org/10.14710/Mmh.46.4.2017.336$342>$.

Eka NAM Sihombing, 26 Maret 2015, Penyelesaian Sengketa Pemilukada Pasca Putusan Mk

97/Puu-Vi/2013,

Dalam

Https:/ Ppkjatiwaras.Wordpress.Com/2015/03/26/Penyelesaian-Sengketa-

Pemilukada-Pasca-Putusan-Mk-Nomor-97puu-Xi2013/, Downloaded on Friday 7 August 2015, 01:51.

Jimly Asshiddiqie, 2012, Hukum Acara Pengujian Undang-Undang, Jakarta : Sinar Grafika, Hal. 211

Saifudien Djazuli, Agustus 2014 01:40, Peran Dan Fungsi Mahkamah Konstitusi, Dalam Http:/ / Apafungsinya.Blogspot.Com/2014/08/Peran-Dan-Fungsi-Mahkamah-

Konstitusi.Html, Downloaded on Wednesday, 5 August 2015, 23:13

Saragih, M. Y. (2020). Law, Journalistic Profession and Mass Media Ethics. Budapest International Research and Critics Institute-Journal (BIRCI-Journal) Volume 3, No 4, Page: 2568-2574.

Susana Rita Kumalasanti, Rabu 7 Januari 2015, Saat Konsistensi Putusan Dipertanyakan, Dalam

Http:/ Nasional.Kompas.Com/Read/2015/01/07/13000061/Saat.Konsistensi.Putus an.Dipertanyakan., Downloaded on Friday, August 2015, 01:31

Verena Klappstein \& Maciej Dybowski (Editors), Ratio Legis: Philosophical and Theoretic Perspective, (Switzerland: Springer, 2018), p. 9 